\title{
Study on the Development Path of the Mixed Ownership Vocational Colleges
}

\author{
Xianzhang Xin \\ Dalian Vocational Technical College \\ Dalian, China
}

\begin{abstract}
Chinese government put forward "to explore the development of vocational colleges with the system of joint stock and mixed ownership". It provides a strong guarantee for further enriching various forms of the mixed ownership and improving the quality of personnel training in vocational colleges under the new situation. Besides, it has great significance both in theory and reality for creating the multiple subjects education pattern. The paper mainly discusses the connotation, approaches, and security system of mixed ownership vocational colleges based on the reality of China's vocational education.
\end{abstract} path

Keywords-mixed ownership; vocational colleges; development

\section{INTRODUCTION}

Chinese government issued the "the decisions of the State Council on accelerating the development of modern vocational education" in June 2014, and explicitly put forward that "In order to explore the development of joint-stock and mixed ownership vocational colleges, capital, knowledge, technology, management and other elements are allowed to get involved in running schools and enjoy the corresponding rights." We should actively support diversified subjects running vocational education through sole proprietorship, joint venture, and cooperation to offer new ideas for the healthy development of vocational education.

\section{THE CONCEPT AND CONNOTATION OF THE MIXED OWNERSHIP VOCATIONAL COLLEGES}

Mixed ownership economy refers to the structure of property distribution and realization formed by property subjects of state-owned, collective, and non-public capital through diversified investments, mutual connections and fusion in the same organization [1]. Learning from the reform experience in economic field, mixed ownership vocational colleges integrate different property subjects into a new interest community by the school-running modes of the nonpublic subjects including state-owned and collective capital as well as private and foreign capital, which represent the new direction of the development of modern school system.

\section{A. Invested Jointly by the Ownerships of Different Nature,} the Schools Show Diversified Property Structure

Mixed ownership vocational colleges are the economic subjects formed by joint capital and fusion or shares. It becomes a necessary condition of mixed ownership subjects that "more than two school subjects" and "there should exist at least one public and one non-public capital subject simultaneously ". Mixed ownership vocational colleges absorb different educational resources; as a result, they realize the effective allocation of social resources, and offer necessary and beneficial supplement to public capital; in the meanwhile, they provide space and channels of education investment for nonpublic capital.

\section{B. The Operating Mechanism of Mixed Ownership Vocational Colleges Has the Typical Market Characteristics}

At present, due to excessive relliance on government, public higher vocational colleges are short of power of selfdevelopment and self-innovation, responsibility awareness of independent operation and vitality of open education, and autonomy of personnel and financial management as well as decision-making and so on; as a result, the colleges have not yet formed a truly independent subject on school running. While mixed ownership vocational colleges can eliminate the development obstacles of the system and mechanism to some extent, and release greater development potentials and powers of the school subjects.

\section{Mixed Ownership Vocational Colleges Diversify in Governing}

As the institutions that various subjects of property rights manage jointly, the ideas of development and cultural temperament of the mechanism of mixed ownership vocational colleges is different from traditional public and private colleges, and they have more modern characteristics in governance methods, structures and systems. The modern managing structures of the juridical persons in mixed ownership vocational colleges emphasize multiple not single subject management; they pay attention to democratic, participatory, interactive management to prevent the phenomenon of "internal control"; and gradually form a balanced system of the decision-making, implementation and power supervision. 


\section{TO EXPLORE THE PRACTICAL SignifiCANCE OF THE DEVELOPMENT OF MIXED OWNERSHIP VOCATIONAL COLLEGES}

\section{A. It Is Conducive to Attracting a Variety of Capital} Ownership into the Field of Vocational Education, and Enrich the Form and Connotation of Mixed Ownership Economy

As an efficient microeconomic system, mixed ownership has great success in the economic field. Applying mixed ownership from economy field to the field of education, and actively exploring and developing mixed ownership vocational colleges is beneficial to attract all kinds of capital ownership into vocational education field. It has a coordinated development of the ownership forms of different natures, and improves the vigor and vitality of development of Chinese higher vocational education.

\section{B. It Is Conducive to Deepening the Reform of Higher Vocational Education System}

The running system of Chinese higher vocational education takes the state as the main body, and the development modes of vocational colleges are similar: generally lacking vitality and the power of independent innovation. While developing mixed ownership vocational colleges can effectively eliminate system defects, diversify school running and its subjects to promote the management structure of vocational colleges and the sound government-oriented education system with the features of social participation, diversification of school running subjects, and various forms of school running system.

\section{It Is Conducive to the Establishment of Market Operating Mechanism and the Enterprises System of Deep Participation}

Mixed ownership vocational colleges accelerate the healthy development of higher vocational colleges through the market operation mechanism and enterprise management ideas. The nature of mixed ownership is that the diversification of property rights and the cross-investment of different capital should be fit for the open education requirements and rules of vocational education systems, schools, industries and enterprises. At the same time, the mixed ownership itself has a mature market operation mechanism, and it can increase investment and output effects for enterprises' participation in vocational education, and ensure the status of enterprises as main body of school-running.

\section{It Is Conducive to Broadening the Sources of School Funding}

It is unbalanced in vocational education funding around China. Besides, traditional public vocational colleges are excessively dependent on government funding, and they make the lack of investment in education becoming a bottleneck which restricts the healthy development of vocational colleges. However, traditional business investment, college-run enterprises, social donations and other means can not become stable sources of school funding. Developing mixed ownership vocational colleges is helpful to enlarge the public education capital and absorb more social capital into vocational education to ease the shortage of funds of vocational education.

\section{E. It Is Conducive to Strengthening the Integration of Business and Education}

Mixed ownership vocational colleges can effectively build durable and deep interest links between occupation colleges and enterprises to form a strong common destiny between occupation colleges and enterprises. It solves the problem of the lack of subjects in higher occupation education run by enterprises in China, and integrates education and occupation organically to further matain organic and effective connection between occupation colleges and enterprises which realize the deep integration of business and education, Cooperative education of schools and enterprises aiming at promoting the upgrading of the educating level and quality of personnel training in higher occupation colleges.

\section{TO EXPLORE THE MAIN APPROACHES OF THE DEVELOPMENT OF MIXED OWNERSHIP VOCATIONAL COLLEGES}

From the aspects of ownership, management and operation mechanism, the mixed ownership vocational colleges are in a intermediate state of " non public nor private ". On macro level, we should promote steadily the formulation of laws and regulations of classification management in for-profit and nonprofit private vocational colleges, and implement the "negative list" management of for-profit private vocational colleges as well as loose access administration in the process of vigorously promoting and supporting the development of nonprofit private occupation colleges. On meso level, local governments can seize the typical cases, sum up experience, emancipate the mind, adjust measures to local conditions, and improve the occasion to create a more relaxed environment for "mixed ownership" education as well as build a more open system platform. On micro level, we should encourage the occupation colleges to have courage to explore and innovate, strive to break a new path in the multi-input, multi-lateral coperation, and various development: establishing the leadership mechanism of community management, creating a complementary mechanism of community of teachers, cultivating construction mechanism of professional community, building innovation mechanism of production and research community, and constructing mutual assistance mechanism of community resources.

\section{A. Public Vocational Colleges Should Be Encouraged to Attract Private Capital}

We can open some high-quality public vocational colleges to private capital and bring in high-quality enterprises or foreign high-quality education groups to form "mixed" property rights relationship. Hangzhou vocational and technical college began to bring in enterprises' leadership mechanism of management community since 2008. Firstly, the school builds a complementary mechanism of teachers community: the school provides the positions of part-time teachers for some enterprise technicians, and enterprises hire professional teachers to work as managers. Secondly, it cultivates construction mechanism of professional community: 
enterprises give requirements and standards of new jobs, determine the orientation of talent cultivation and professional settings, and make professional teaching plans with the school. Thirdly, it creates an innovation mechanism of production and research: it builds the cooperative training center, research and development platform, and productive projects. Fourthly, it constructs assistance mechanism of resources community: it combines the support of enterprise resource and speciality settings. Fifthly, it achieves the integration mechanism of cultural community and promotes the deepening of school and business culture gradually.

\section{B. Public Capital Is Infused into Private Vocational Colleges}

Lacking support of the national finance, private vocational colleges have general problems of the shortage of funds for running schools, the single financing channels and the lack of stamina development. The government can offer financial support to the reputable private occupation colleges with distinct characteristics under their jurisdiction by means of capital injection, the services of government procurement, government subsidies and so on.

\section{Public Higher Vocational Colleges Take Over Private Schools}

For the private higher vocational colleges that lack well management and good benefit, government or education authorities should make them being taken over by public schools of high educating level after considering comprehensively the factors of the schools such as professional structure, geographical location, and facilities conditions. Besides, in order to solve the problem of the survival and resource utilization, private vocational colleges become shareholders by their owned assets of private colleges.

\section{Different Forms of Ownership of Capital Is Invested in New Vocational Colleges}

Non-public capital such as state-owned capital, collective capital and private capital can be co-invested in the building of higher occupation colleges, schools should be encouraged to take the mixed ownership model since its establishment. Hainan college of vocation and technique is established jointly by the Education Department of Hainan Province, Haikou agricultural and industrial trade company limited by shares and Hainan radio and television university. It implements principal accountability system under the leadership of the board of director, and the internal governance and the operation mechanism should also follow the requirements of education as well as the mode of enterprise management. At the same time, it should actively seek cooperation with foreign vocational education institutions, and bring in foreign highquality educational resources to form a number of high-level and international vocational colleges rapidly.

\section{TO EXPLORE THE DEVELOPMENT OF SECURITY SYSTEM OF MIXED OWNERSHIP VOCATIONAL COLLEGES}

\section{A. To Establish a Sound Correlative Legal System and Regulations}

There still exist some problems in the construction of mixed ownership vocational colleges in China, such as unsound legal system, incomplete top design and system framework of the reform program. Education authorities should formulate the reform rules of mixed ownership vocational colleges as soon as possible and put forward clearly the complementary legal basis of legal status, the property of legal person, governance structure, property ownership, income allocation, and supervision mode of the vocational colleges that implement mixed ownership. We should propose the classification principles, supportive policies, and the basic operation in the process of public vocational colleges exploring the mixed ownership [2].

\section{B. To Establish a Sound Corporate Governance}

The multi-subject of the mixed ownership vocational colleges determines that there must be some breakthroughs and innovations in school governance. The process of establishing mixed ownership, in fact, is the process of improving corporate governance. In order to improve the governance structure of mixed ownership vocational colleges, we can't just mix it in form but give corresponding discourse and decision-making powers to the shared capital and gradually improve the rules of procedure to enhance democratization and transparency of decision-making, keep balance among the investors, managers, executives, and the vocational colleges staff. The measures are taken to protect the legitimate rights and interests of the cooperations.

\section{To Establish the Sound Property Protection and Flow Mechanism}

We should explore to establish transaction centers of education assets property which are suitable for the development of mixed ownership vocational colleges, reduce the risk of education capital flow and uncertainty, and build a normative, honest and transparent trading platform to ensure the legitimate process of transactions including asset merger of vocational colleges, joint occupation colleges, contract, and equity transfer. In the meanwhile, in the process of exploring the development of mixed ownership vocational colleges, we can not simply copy the company's business model to prevent excessive marketization, but respect the nature of capitalfollow-profitability to effectively guide non-public capital's expectation of capital returns and protect its income rights and residual rights of investment.

\section{To Deepen the Reform of the Management System of State Education Resources and the Mode of Educational Administration}

In order to implement the school-running autonomy of vocational colleges and reduce administrative intervention on the specific educational process gradually, what we should do especially is to ensure that vocational colleges themselves manage the professional development and construction, the 
reform of education and teaching, the development of technology and service, management, and teacher assessment and appointment. Government departments should create a better environment and establish a guidance as well as safeguard mechanism for the mixed ownership vocational colleges. They also should check and supervise scientifically the running cost and benefits of ownership vocational colleges, and supervise strictly and effectively on the use and transfer of national asset in the mixed ownership vocational colleges.

\section{CONCLUSION}

The development of mixed ownership vocational colleges is a new thing. It is a major innovation in school-running system. Similar to other reforms, the reform of mixed ownership vocational colleges can not be achieved overnight for there are few ready-made modes to refer to. We can not copy the practices of other countries, and the path is doomed to be tortuous and bumpy. We can do is only further exploring it in practice according to national conditions and improve constantly.

\section{REFERENCES}

[1] Chang Xiuze: The Foundation of Socialist Market Economy System: Mixed Ownership Economy, Guangming Daily, Fifteenth Edition in July 2, 2014.

[2] An Rongquan: Some Rational Thinking on Exploring the Mixed Ownership Vocational Colleges, China Higher Education Research, The Fourth Issue of 2015 95-98 pages.

[3] Liu Hongyi: How Do Vocational Colleges Make Attempt on Mixed Ownership, Guangming Daily, August 11, 2015. 